\title{
Foreword. On Pluriversality and Multipolarity
}

Over a fourteen- to fifteen-year span starting in 1995 , I used the concept of pluriversality in many instances in my work. ${ }^{1}$ I first heard of the concept during the early years of the Zapatista uprising. Franz Hinkelammert introduced the concept, as far as I know, and Enrique Dussel was using it during that period, and it fit perfectly well with the idea of pluritopic hermeneutics that I had borrowed from Raymundo Pannikar - an idea that became central to my argument in The Darker Side of the Renaissance (Mignolo 1995). But it was the Zapatistas' own decolonial political vision of a world in which many worlds would coexist that announced the pluriverse. The ontology of the pluriverse could not be obtained without the epistemology of pluriversity.

Epistemology and hermeneutics, in the Western genealogy of thought, investigate and regulate the principles of knowledge, on the one hand, and the principles of interpretation, on the other. Both strains are embedded in the self-proclaimed universality of Western cosmology and act as its gatekeepers. Together, epistemology and hermeneutics prevent the possibility of pluriversality, with all its internal diversity, and close off ways of thinking and doing that are not grounded in Western cosmology. The way out is the decolonial restoration of gnoseology fueling the march toward pluriversality.

When you-scholar, intellectual, journalist, or some such, trained in Western epistemology — have to navigate two or more cosmologies, as I had to while writing The Darker Side of the Renaissance, you need a point of reference that is contained in neither epistemology nor hermeneutics. I had recourse to the concept of pluritopic hermeneutics, which I adapted from Raimon Panikkar's (2017) diatopical hermeneutics. Although hermeneutics is retained, it is also reduced to size and to its restricted domain: namely, the provincial, universal assumptions sustaining Western cosmology. Gnoseology came to the rescue and I introduced it later on in Local Histories/Global Designs (Mignolo 20I2c).

Why did Panikkar need diatopical hemeneutics, and why did I need pluritopic hermeneutics? Because I was dealing with a pluriverse of meaning. Pluriversality became my key argument for calling into question the concept of universality, so dear to Western cosmology. How so? Western epistemology and hermeneutics (meaning the Greek and Latin languages, translated into the 
six modern European and imperial languages) managed to universalize their own concept of universality, dismissing the fact that all known civilizations have been founded on the universality of their cosmologies. The West's universalizing tendency was nothing new, but it claimed a superior position for itself. The pluriverse consists in seeing beyond this claim to superiority, and sensing the world as pluriversally constituted. Or, if you wish, pluriversality becomes the decolonial way of dealing with forms of knowledge and meaning exceeding the limited regulations of epistemology and hermeneutics. Consequently, pluriversality names the principles and assumptions upon which pluriverses of meaning are constructed.

There is no reason to believe that the Bible is universal and the Popol Vuh is not. However, delinking from the Western universal is nonetheless a difficult decolonial task. The universalization of Western universality was part of its imperial project. Accordingly, a key idea in Local Histories/Global Designs: Coloniality, Subaltern Knowledges, and Border Thinking (Mignolo 2000a) was to argue for pluriversality as a universal project. Pluriversality as a universal project is aimed not at changing the world (ontology) but at changing the beliefs and the understanding of the world (gnoseology), which would lead to changing our (all) praxis of living in the world. Renouncing the conviction that the world must be conceived as a unified totality (Christian, Liberal, or Marxist, with their respective neos) in order for it to make sense, and viewing the world as an interconnected diversity instead, sets us free to inhabit the pluriverse rather than the universe. And it sets us free to think decolonially about the pluriversality of the world rather than its universality.

Consequently, pluriversality as a universal project means that the universal cannot have one single owner: the universal can only be pluriversal, which also corresponds with the Zapatistas' vision of a world in which many worlds coexist. All of us on the planet have arrived at the end of the era of abstract, disembodied universals - of universal universality. Western universalism has the right to coexist in the pluriverse of meaning. Stripped of its pretended universality, Western cosmology would be one of many cosmologies, no longer the one that subsumes and regulates all the others.

Thus conceived, pluriversality is not cultural relativism, but the entanglement of several cosmologies connected today in a power differential. That power differential, in my way of thinking and doing, is the logic of coloniality covered up by the rhetorical narrative of modernity. Modernity-the Trojan horse of Western cosmology-is a successful fiction that carries in it the seed of the Western pretense to universality. Expanding on this line of reasoning, it was necessary to introduce a concept that could capture the "/" of modernity/ 
coloniality, that is, the "/" between the entanglement and the power differential. And that concept was rendered as border thinking, border epistemology, border gnosis.

If a pluriverse is not a world of independent units (as is the case with cultural relativism) but a world entangled through and by the colonial matrix of power, then a way of thinking and understanding that dwells in the interstices of the entanglement, at its borders, is needed. So the point is not to study the borders while still dwelling in a territorial epistemology you are comfortable with. Such an approach would imply that you accept that there is a pluriverse someplace out there, but that you observe it from someplace else, somewhere outside the pluriverse.

To do so is necessarily to maintain the territoriality of the disciplines, grounded in the imperial epistemology of modernity. To think pluritopically means, instead, to dwell in the border. Dwelling in the border is not border crossing, even less looking at and studying the borders from the territorial gaze of the disciplines. Today border studies have become fashionable, even in Europe. Scholars studying borders are for the most part not dwelling in them. The people who dwell in the border are the migrants from Africa, west Asia (the socalled Middle East), and Latin America, predominantly. That's what I learned from Gloria Anzaldúa. Like migrants and queers, Chicanos and Chicanas are always dwelling in the border, whether they are actual migrants or not.

I think the impact that Local Histories/Global Designs had was owed to the fact that it was written while inhabiting the border. I did not observe the border; I inhabited it. As a matter of fact, it was my awareness of inhabiting the border that prompted the book. I needed to write from inside the border rather than write about the border while inhabiting the territory (be it a nationality or a discipline).

In the preface to the second edition of the book (Mignolo 2012c), I revealed a secret: that the argument was a rewriting of Hegel's philosophy of history from the position of inhabiting the border. Hegel—as I read him-was well grounded in the territory. For him, there was nothing else but the territory. But I was not there. So border thinking and doing (or, in this case, writing) became the way (as in Buddhism) or the method (as in Western sciences, social or not) of decolonial thinking and doing-a way and a method with infinite possibilities and permutations, to be sure, not constrained or prescriptive in its direction.

This combination of border thinking and border doing was a key point in moving away from the ideological trap that distinguishes theory from praxis. Reflexive praxis is, instead, the founding principle of Amawtay Wasi (Universidad Intercultural de las Nacionalidades y Pueblos Indígenas Amawtay Wasi). Why? Because its very educational project is built on border epistemology. It relies on 
indigenous and Andean cosmology—not rejecting indigenous European cosmology but embodying it within Andean cosmology-thus a cosmovivencia (Huarachi 20II). ${ }^{2}$

I learned from indigenous cosmology what I couldn't learn from Hegel and Western cosmology. However, I was trained (in body and mind) in the latter. Learning from what Western modernity had disavowed, and not observing and describing what modernity disavowed, opened up new dimensions of the border to me. Sensing that border is not a mental or rational experience, I sensed it, and sensing is something that invades your emotions, and your body responds to it, dictating to the mind what the mind must start thinking, changing its direction, shifting the geography of reasoning. Pluriversality for me goes in tandem with the enactment of border thinking, and not with the description of border thinking that happens not in yourself but someplace else.

In The Darker Side of Western Modernity (Mignolo 201I), I returned to pluriversality and the pluriverse of meaning, connecting it with the idea of the multiverse in Humberto Maturana's epistemology. The multiverse is for Maturana a world of truth in parentheses, while the universe is a world built on truth without parentheses-unqualified, unconditional. Universality is always imperial and war driven. Pluri- and multiverses are convivial, dialogical, or plurilogical. Pluri- and multiverses exist independently of the state and corporations. It is the work of the emerging global political society-that is, the sector of society organizing itself around specific projects, having realized that neither the state nor the corporation has room for multi- or pluriverses.

While multi- and pluriverses characterize the essence of the global political society, in the realm of the state and the corporations the vocabulary is that of a multipolar world. The multipolar world of today has been opened up by the economic growth and political confidence of China's interstate politics, together with the BRICs (Brazil, Russia, India, China, South Africa) nations, the growing economics and politics of Indonesia and Turkey, and the Latin American states in Mercosur, following the leadership of Brazil. When Vladimir Putin "stole" Barack Obama's threat of invading Syria, it was evident that the unipolar world that made the invasion of Iraq possible was no longer in place. And it seems obvious, too, that Putin's chess move was enabled by the support of the BRICS alliance, of which he is the current chair. Thus, I would like to use pluriversity in the sphere of the decolonial projects emerging out of the global political society (deracializing and depatriarchizing projects, food sovereignty, reciprocal economic organization and the definancialization of money, decolonization of knowledge and of being, decolonization of religion as a way to liberate spirituality, decolonization of aesthetics as a way to liberate esthesis, 
etc.) and multipolarity in the sphere of politico-economic dewesternization, led by state projects.

Despite their different spheres of reference, these two expressionspluriversity and multipolarity - are today both used to underscore the disintegration of Eurocentrism. Eurocentrism is synonymous with Westernization (Latouche 1982). Eurocentrism was the partition of the globe by European institutions and actors to the benefit of Europe and the core Western states. The United States followed suit after World War II. By 2000, the signs marking the end of Westernization were no longer possible to ignore. It is not only that there were no more places to expand into: the reemergence of the disavowed was also becoming loud and clear. Indeed, the multipronged struggle for decolonization during the Cold War (and the Bandung Conference of I955) had been an especially eloquent sign of the end of an era-an era that can be traced from 1500 all the way to 2000 , roughly speaking. On the other hand, China's millennial comeback after the humiliation it suffered during and after the Opium Wars was sending strong signs to whoever was paying attention.

Now we, on the planet, are experiencing the consequences of decoloniality after decolonization and the consequences of dewesternization after the Cold War (Mignolo 20I2b). Dewesternization (led by BRICs, Iran) has already mapped the multipolar world of the twenty-first century. This multipolar world is capitalist and decentered. As a result of this decentering, the United States, seconded by the European Union, is having more and more difficulty imposing its will and desires on the rest of the planet. Strong states have emerged whose leaders refuse to have bosses and receive orders (e.g., Ukraine, West Asia, the China Development Bank and the BRICs bank, and China and Russia's military affirmation). Therefore, the multipolar world arises out of the conflicts between dewesternization and the response to it being mounted by the West: namely, rewesternization, the effort to not lose the privileges acquired over the past five hundred years.

Westernization was defined by a coherent set of global designs. Intramural wars (the Thirty Years' War, World War I, and World War II) emerge from intramural conflicts in the process of Westernization. Dewesternization, on the other hand, is a heterogeneous set of responses disputing the unipolar management of the world's population and natural resources. If Westernization was unipolar, dewesternization is multipolar. Unipolarity was successful in enacting the global designs associated with Westernization. Multipolarity, on the other hand, can no longer be controlled by global designs; it fractures them, by definition. Indeed, multipolar processes are processes of de-designing. Dewesternization is the de-designing of Westernization. 
Decoloniality, on the other hand, does not compete with dewesternization and rewesternization, but rather aims to delink from both-that is, to delink from state forms of governance, from the economy of accumulation, and from the ego-centered personalities that both enacted and reproduced Westernization: the modern subject forcing the formation of colonial subjects. Crucially, decoloniality is not a master plan or a global design. It is, above all, a diverse horizon of liberation for colonial subjects, constructed by the colonial subjects themselves. There cannot be a decolonial global design, for if that were the case, it would merely be the reproduction of ego-centered personalities who claim to hold the master key of decoloniality. Decoloniality starts with the transformations and liberations of subjectivities controlled by the promises of the state, the fantasies of the market, and the fears of armed forces, all tied together by the messages of mainstream media.

While ego-centered personalities and modern subjects are subjectivities formed in and by the processes of Westernization and Eurocentrism, decolonial processes emerge from an analysis and awareness of the promises of modernity and the disenchantments of coloniality. If, then, state-led dewesternization is forcing the formation of a multipolar world order, decoloniality is opening the horizon of a pluriversal world. Pluriversality, contrary to de- and rewesternization, focuses not on the state, the economy, or the armed forces, but on delinking from all of these forces. Decolonial delinking, however, should benefit from and draw on dewesternization, to the extent that dewesternization is fracturing the ambitions of Westernization-of which the process of neoliberalism was its last desperate attempt (Mignolo 2002).

Modern ego-centered personalities are driven by competition; decolonial and communal personalities are driven by the search for love, conviviality, and harmony (Mignolo 200ob). For this reason, decoloniality cannot aim to take the state, as was the aim of the decolonization movements during the Cold War. And so decoloniality also delinks from Marxism. Indeed, it withstands alignment with any school or institution that would divert its pluriverse back into a universe, its heterogeneity back into a totality.

\section{ACKNOWLEDGMENTS}

Thank you to Sandra Harding, whose work has inspired me and who has been a mentor over the past years, always ready to offer advice, insight, and help. Academic work would be so much more fun and so much more relevant at the same time could it count on more scholars like you! 
Thank you to Arturo Escobar for his generosity, brilliance, kindness, and support.

Thank you to Ulrich Oslender for standing with me in this project and others.

Thank you to my students, many of whom have long seen through the universalist claims of the white European males we read in our seminars and demanded more diverse and pluriversal approaches.

Thank you to my department and chair for supporting this project.

I received a small grant from the University of South Florida's Publishing Council. Thank you!

I want to dedicate this foreword to my wife, Miranda.

\section{NOTES}

I. The first time I introduced pluriversity into my argument was in a series of lectures delivered between 1996 and 1998. Later, in 2002, I published an essay on the subject in Binghamton University's Review: A Journal of the Fernand Braudel Center, under the title "The Zapatistas' Theoretical Revolution: Its Historical, Political, and Epistemological Consequences." The essay appeared, slightly revised, as a chapter in The Darker Side of Western Modernity (Mignolo 20II).

2. In a similar strain, Oyeronke Oyewumi (1997) rejects the idea of a world "view" as a European way of favoring the visual. Oyewumi instead proposes the concept "world-sense."

\section{REFERENCES}

Huarachi, Simon Yampara. 2011. "Andean Cosmovivencia: Living and Living Together in Integral Harmony-Suma Qamaña.” Bolivian Studies Journal I8:I-22.

Latouche, Serge. 1982. L'occidentalization du monde. Paris: La Découverte.

Mignolo, Walter D. 1995. The Darker Side of the Renaissance: Literacy, Territoriality, and Colonization. Ann Arbor: University of Michigan Press.

Mignolo, Walter D. 2000a. Local Histories/Global Designs: Coloniality, Subaltern Knowledges, and Border Thinking. Princeton, NJ: Princeton University Press.

Mignolo, Walter D. 200ob. "The Many Faces of Cosmo-polis: Border Thinking and Critical Cosmopolitanism." Public Culture I2 (3): 72I-48.

Mignolo, Walter D. 2002a. "The Enduring Enchantment: (Or the Epistemic Privilege of Modernity and Where to Go from Here)." South Atlantic Quarterly IOI (4): 927-54. http://waltermignolo.com/wp-content/uploads/2013/03 /enchantment.pdf.

Mignolo, Walter D. 2002b. “The Zapatistas' Theoretical Revolution: Its Historical, Political, and Epistemological Consequences." Review: A Journal of the Fernand Braudel Center 25 (3): 245-75.

Mignolo, Walter D. 20II. The Darker Side of Western Modernity: Global Futures, Decolonial Options. Durham, NC: Duke University Press. 
Mignolo, Walter D. 2012a. The Darker Side of the Renaissance: Literacy, Territoriality, and Colonization, 2nd ed. Ann Arbor: University of Michigan Press.

Mignolo, Walter D. 20ı2b. "Delinking, Decoloniality and Dewesternization: Interview with Walter Mignolo (Part II)." Critical Legal Thinking, May 2. http://criticallegalthinking .com/2012/05/02/delinking-decoloniality-dewesternization-interview-with-walter -mignolo-part-ii/.

Mignolo, Walter D. 2012c. Local Histories/Global Designs: Coloniality, Subaltern Knowledges, and Border Thinking, 2nd ed. Princeton, NJ: Princeton University Press.

Oyewumi, Oyeronke. 1997. The Invention of Women: Making and African Sense of Western Gender Discourses. Minneapolis: University of Minnesota Press.

Panikkar, Raimon. 2017. “Diatopical Hermeneutics.” http://www.raimon-panikkar.org /english/gloss-diatopic.html. 